\title{
MEMAHAMI POLA IJTIHAD DALAM MODERNISASI HUKUM WAKAF DI INDONESIA
}

\author{
Athoillah Islamy, Alfiandri Setiawan, Nuryasni Yazid \\ 1Institut Agama Islam Negeri Pekalongan, 2Universitas Islam Negeri Sultan \\ Syarif Kasim Riau, ${ }^{3}$ Pemerintah Daerah Kabupaten Bengkalis \\ athoillahislamy@yahoo.co.id setiawanandi963@gmail.com \\ nuryasniyazid79@gmail.com
}

\section{Abstract :}

This study aims to find the pattern of ijtihad in the renewal of waqf law in Indonesia as stipulated in Law No. 41 of 2004. The focus of the object of this research is Article 1 regarding the existence of waqf, Article 16 regarding waqf objects, and Article 40 concerning changes in the status of property. waqf. This research is a qualitative research in the form of literature review. This type of Islamic legal research is included in the category of philosophical normative legal research. The analytical theory used is the contemporary typology of ijtihad proposed by Yusuf al-Qaradawi. This research concludes that the construction of waqf legal reform in Article 1 regarding the existence of waqf, Article 16 regarding the object of waqf, and Article 40 regarding changes in the status of waqf assets tends to use the ijtihad intiqa'i approach, which is to choose a legal opinion of the classical fiqh school which is relevant to developmental conditions and needs of modern society. However, in article 40 , the author considers that there is a selection of legal opinions from the jurisprudence schools that do not allow to sell or replace waqf objects which will cause problems in their application. This is because the waqf object in certain conditions can suffer damage and loss of benefit. Therefore, the legal construction in article 40 can be reconsidered.

Keywords: Ijtihad, Renewal, Waqf, Indonesia

\section{Abstrak:}

Penelitian ini bertujuan untuk menemukan pola ijtihad dalam pembaharuan hukum wakaf di Indonesia yang termaktub dalam Undang-undang No.41 Tahun 2004. Fokus objek penelitian ini pada Pasal 1 terkait eksistensi wakaf, Pasal 16 tentang benda wakaf, dan Pasal 40 tentang perubahan status harta 
benda wakaf. Penelitian ini merupakan penelitian kualitatif yang berupa kajian pustaka. Jenis penelitian hukum Islam ini masuk kategori penelitian hukum normatif filosofis. Teori analisis yang digunakan, yakni tipologi ijtihad kontemporer yang dicetuskan Yusuf al-Qaradawi. Penelitian ini menyimpulkan kontruksi pembaharuan hukum wakaf dalam Pasal 1 terkait eksistensi wakaf, Pasal 16 terkait objek wakaf, dan Pasal 40 terkait perubahan status harta benda wakaf cenderung menggunakan pendekatan ijtihad intiqa'i, yakni memilih pendapat hukum mazhab fikih klasik yang relevan dengan kondisi perkembangan dan kebutuhan masyarakat modern. Namun dalam pasal 40, penulis memandang terdapat pemilihan pendapat hukum dari mazhab fikih yang tidak membolehkan untuk menjual atau mengganti benda wakaf akan dapat menimbulkan problem dalam aplikasinya. Hal demikian disebabkan benda wakaf dalam kondisi tertentu dapat mengalami kerusakan dan hilangnya kemanfaatan. Oleh sebab itu, konstruksi hukum dalam pasal 40 dapat dipertimbangkan kembali.

Kata Kunci : Ijtihad, Pembaharuan, Wakaf, Indonesia

\section{A. PENDAHULUAN}

Fenomena kemiskinan maupun kesenjangan sosial ekonomi di negara yang mayoritas penduduknya beragama Islam merupakan hal yang memperihatinkan. ${ }^{1}$ Jika dicermati secara empiris, kondisi penduduk di bawah garis kemiskinan tidak mesti disebabkan oleh problem kekayaan alam yang tidak sebanding lurus dengan jumlah penduduk, melainkan juga dapat karena rendahnya distribusi dan solidaritas sesama anggota masyarakat. Padahal dalam ajaran Islam sendiri sejatinya terdapat pelbagai ajaran istitusional yang diharapkan dapat menjembatani dalam mewujudkan kesejahteraan sosial. Salah satunya, yakni institusi wakaf. ${ }^{2}$

\footnotetext{
${ }^{1}$ Ajaran Islam memperingatkan pemeluknya agar tidak menganggur sehingga dapat tergelincir ke jurang kemiskinan. Hal demikian disebabkan kondisi kemisikinan dikhawatirkan dapat menjadikan seseorang melakukan perbuatan negatif, termasuk. Bahkan terdapat pernyataan yang termaktub dalam sebuah hadis bahwa kondisi kemiskinan dapat membawa lebih dekat kepada kekafiran. Melis, "Relevansi Agama dan Kemiskinan; Upaya Memahami Kemiskinan Secara Multidimensional dan Solusi yang ditawarkan dalam Ekonomi Islam," SALAM; Jurnal Sosial \& Budaya Syar-i, Vol.6, No.2 (2019):179.

${ }^{2}$ Buku Pedoman Pengelolaan dan Perkembangan Wakaf (Kementrian Agama Republik Indonesia Direktorat Jendral Bimbingan Masyarakat Islam Direktorat Pemberdayaan Wakaf Tahun 2013), 1-2.
} 
Sebagaiamana zakat, ${ }^{3}$ institusi wakaf sejatinya dapat menjadi alat pendongkrak ekonomi umat Islam ketika dikelola dengan tepat. ${ }^{4}$ Menurut sistem ekonomi makro Islam, institusi wakaf memiliki tiga unsur penting. Pertama. wakaf dapat mengurangi tingkat suku bunga (rate of interest). Kedua, wakaf dapat menjadi salah satu mekanisme redistribusi kekayaan. Ketiga, wakaf dapat menjadi mekanisme investasi (saving).5 Oleh sebab itu, tidak berlebihan jika kehadiran wakaf dikatakan memiliki peran strategis dalam memberikan solusi terhadap pelbagai masalah sosial dan ekonomi kemasyarakatan.

Namun dalam ranah praksisnya, pengelolaan wakaf bukanlah hal mudah, melainkan sering menemui hambatan dan tantangan bagi pihak atau lembaga pengelola wakaf (nadzir). ${ }^{6}$ Problem pengelolaan tersebut disebabkan oleh berbagai hal, antara lain. Pertama, stagnasi pemahaman masyarakat atas

${ }^{3}$ Sebagai bentuk ibadah wajib dan rukun rukun Islam, zakat memuat dua dimensi fungsi kepemilikan, yaitu individu dan kepemilikan sosial. Di balik dua dimensi hak tersebut, Zakat memiliki banyak fungsi, termasuk proses ekonomi dan sosial. Oleh karena itu, tidak mengherankan jika Zakat disebut sebagai konsep ajaran Islam paling awal yang mengandung nilai tanggung jawab sosial bersama dalam mewujudkan keadilan sosial Athoillah Islamy, Afina Aninnas, "Zakat And Tax Relation In Muslim Southeast Asian Countries (Comparative Study of Zakat and Tax Arrangements In Indonesia, Malaysia, and Brunei Darussalam)," Li Falah: Jurnal Studi Ekonomi dan Bisnis Islam, Vol.5, No.2 (2020): 102.

${ }_{4}^{4}$ Jika dilacak dalam peradaban masa kejayaan pemerintahan Islam klasik.Pada masa jaman institusi wakaf pernah mencapai kejayaan meskipun strategi pengelolaannya masih sederhana. Pada abad ke-8 dan ke-9 Hijriyyah misalnya, dipandang sebagai masa keemasan perkembangan institusi wakaf. Pada waktu itu, pengembangan produk wakaf meliputi berbagai benda, yakni masjid, mushalla, sekolah, tanah pertanian, rumah, toko, kebun, pabrik, bangunan kantor, gedung pertemuan dan perniagaan, pasar dan lain sebagainya. Masa itu, sultan (penguasa) senantiasa berupaya mendorong dalam pengembangan wakaf terus menerus. Fiqih Wakaf (Proyek Peningkatan Zakat dan Wakaf Direktorat Jenderal Bimas Islam dan Penyelenggaraan Haji, 2003), 85-86.

5Murtadho Ridwan, "Wakaf dan Pembangunan Ekonomi," ZISWAF, Vol. 4, No. 1, (2017): 106.

${ }^{6}$ Secara terminologi, istilah nadzir merupakan pengelola baik perorangan atau lembaga (badan hukum) yang bertugas untuk mendata, mengelola dan meningkatkan produktivitas harta wakaf dalam rangka memberikan manfaat seluas-luasnya bagi penerimanya. Namun penting diketahui kendatipun posisi nadzir dalam wakaf dipandang penting, akan tetapi keberadaan nadzir tidak masuk kategori rukun atau syarat sahnya sebuah wakaf. Hal ini disebabkan wakaf merupakan ibadah sosial (tabarru') yang hukumnya sunnah.Agung Abdullah, "Nadzir dalam Perspektif Kelembagaan Wakaf di Indonesia," Jurnal Ilmiah Ekonomi Islam, Vol.6, No.3 (2020): 404. 
objek wakaf yang hanya terbatas dalam bentuk tanah, bangunan, dan pepohonan. Kedua, pengelolaan wakaf oleh nadzir yang ada kebanyakan masih konvensional tradisional. Belum mengarah pada konsep wakaf secara produktif dalam pemberdayaan ekonomi dan sosial secara lebih luas. Ketiga, masih rendahnya kepercayaan masyarakat terhadap akuntabilitas nadzir dalam pengelolaan harta wakaf. Keempat: lamanya waktu pensertifikatan tanah wakaf juga menjadi kendala tersendiri bagi nadzir. ${ }^{7}$

Pelbagai problem praksis di atas menuntut pentingnya pengelolaan harta wakaf secara profesional dan dinamis mengikuti perkembangan kebutuhan hidup umat yang ada. Dalam konteks inilah, upaya pembaharuan terhadap konstruksi hukum wakaf klasik (tradisional) menjadi hal keniscayaan. Hal demikian tidak lain dimaksudkan agar tujuan dari institusi wakaf dapat berjalan maksimal seiring perkembangan zaman. Tujuan tersebutlah yang kemudian juga mendorong pembaharuan hukum dan pengelolaan wakaf di pelbagai negara muslim modern baik pada aspek regulasi, pelaksanaan maupun pengembangannyastidak terkecuali dalam konteks pembaharuan hukum wakaf di Indonesia, seperti halnya yang termaktub dalam UU. No.41 tahun 2004 tentang wakaf. ${ }^{9}$

Berpijak pada uraian latar belakang di atas, penelitian ini bermaksud untuk melakukan studi analisis terhadap konstruksi metodologis yang digunakan dalam pembaharuan hukum wakaf di Indonesia sebagaimana yang termaktub dalam UU.No.41 tahun 2004 tentang wakaf. Hal demikian ini penting dilakukan untuk memahami sejauh mana pola ijtihad pembaharuan hukum wakaf diaplikasikan dalam rumusan produk regulasi hukum wakaf

\footnotetext{
${ }^{7}$ Ahmad Muslich,"Peluang dan Tantangan dalam Pengelolaan Wakaf," Muaddib, Vol.06 No.2 (2016): 212-213.

${ }^{8}$ Ahmad Suwaidi, "Wakaf Dan Penerapannya Di Negara Muslim," Economic: Jurnal Ekonomi dan Hukum Islam, Vol. 1, No. 230.

${ }^{9}$ Arah pembaruan hukum wakaf Indonesia menuju pemahaman hukum wakaf yang lebih komprehensif, pengembangan tatakelola wakaf yang lebih integratif, dan peningkatan penguatan kapasitas kelembagaan wakaf yang lebih kuat. Miftahul Huda, "Arah Pembaharuan Wakaf Indonesia," Ulumuna :Jurnal Studi Keislaman, Vol.16 No. 1 (2012):125.
} 
dalam UU tersebut. Dengan harapan dapat menemukan pola ijtihad kontemporer yang digunakan di dalamnya. Apakah di dalamnya benar-benar terjadi pembaharuan konstruksi hukum wakaf, atau hanya sekedar mengadopsi pemikiran hukum Islam klasik, sehingga dalam ranah impelementasi praksisnya pada konteks kehidupan modern memungkinkan masih menyisakan problem.

\section{B. LITERATURE REVIEW}

Berdasarkan penelusuran penulis ditemukan berbagai penelitian terdahulu yang relevan dengan objek inti pembahasan pada penelitian ini, antara lain sebagai berikut.

Diawali oleh Miftahul Huda (2012) dalam penelitiannya berjudul "Arah Pembaharuan Hukum Wakaf Indonesia." Huda menyatakan bahwa arah pembaruan hukum wakaf di Indonesia memiliki tujuan guna mewujudkan pemahaman hukum wakaf yang komprehensif, pengembangan tatakelola wakaf yang integratif, dan penguatan kapasitas kelembagaan wakaf. Untuk mencapai tujuan tersebut, maka digunakanlah pelbagai metode dalam konstruksi pembaharuan hukum wakaf yang ada, antara lain metode talfiq seperti takhsis al-qadhā, tahyīr, talfiq, dan siyāsah shar'iyyah., ${ }^{10}$ Penelitian Huda tersebut mencoba menggali aspek metode yang digunakan dalam pembaharuan hukum wakaf pada UU No.41 tahun 2004. Hanya saja temuan dalam penelitian tersbut mengacu pada metode pembahruan hukum perdata (perkawinan) Islam modern secara umum. Berbeda dengan penelitian ini yang akan menggunakan kerangka tipologi ijtihad hukum Islam kontemporer yang dicetuskan Yususf al-Qaradawi.

Kemudian penelitian Ibrahim Siregar (2012) dalam penelitian berjudul "Pembaharuan Hukum Perakafan di Indonesia," Ibrahim menyatakan bahwa

${ }^{10}$ Miftahul Huda, "Arah Pembaharuan Wakaf Indonesia," Ulumuna :Jurnal Studi Keislaman, Vol.16 No. 1 (2012). 
dengan berkembangnya pemikiran hukum Islam (fikih) para ulama di Indonesia, maka berdampak pada pembaharuan regulasi hukum wakaf beserta pengelolaannya di Indonesia, yakni berubah menuju hukum wakaf progresif. Menurut Ibrahim, perkembangan hukum wakaf tersebut dapat dilihat dalam pelbagai ketentuan hukum wakaf yang termaktub dalam UU Wakaf No 41 tahun 2004 tentang Wakaf.11

Sebagaimana Ibrahim Siregar, Asni (2014) dalam penelitian yang berjudul "Pengembangan Hukum Perwakafan di Indonesia"menuturkan bahwa pelbagai upaya pembaruan hukum wakaf di Indonesia meliputi pengaturan administratif, seperti pencatatan dan sertifikasi tanah wakaf maupun pengembangan objek wakaf. Asni menambahkan bahwa upaya pengembangan tersebut secara metodologis dilandaskan pada asas kemanfaatan, dalam rangka merealisasikan kemaslahatan yang menjadi tujuan pokok pensyariatan hukum Islam itu sendiri. ${ }^{12}$ Baik penelitian Ibrahim maupun Asni di atas, keduanya mencoba mendiskripsikan orientasi pembaharuan hukum wakaf di Indonesia sebagaimana yang termaktub dalam UU No.41 tahun 2004 tentang wakaf.

Kemudian paralel dengan Ibrahim dan Asni, Moh Luthfi (2019) dalam disertasinya yang berjudul "Pergeseran Paradigma Perwakafan Di Indonesia (Studi Analisis Hukum Wakaf Sebelum Dan Sesudah Berlaku Undang-Undang No. 41 Tahun 2004Tentang Wakaf)"menyatakan bahwa konstruksi hukum dalam peraturan perundangan wakaf sebelum UU. No.41 tahun 2004 lebih mengacu pada pendapat hukum dari beberapa madzhab. Hal ini berbeda setelah lahirnya UU No. 41 yang lebih cenderung mengakomodir seluruh madzhab empat dengan disesuaikan perkembangan perwakafan di Indonesia dan dunia

\footnotetext{
${ }^{11}$ Ibrahim Siregar, "Pembaharuan Hukum Perwakafan di Indonesia," Jurnal Tsaqafah, Vol.8, No.2 (2012).

${ }^{12}$ Asni, "Pengembangan Hukum Perwakafan di Indonesia," Jurnal Al-'Adl, Vol.7, No.2 (2014).
} 
Islam. ${ }^{13}$ Penelitian disertasi Moh Luthfi ini mencoba mengurai kecenderungan pengaruh mazhab fikih (mazhab empat) dalam pembaharuan pelbagai ketentuan hukum wakaf di Indonesia, baik pra maupun pasca diberlakukan UU. No.41 tahun 2004 tentang wakaf.

Senada dengan Moh. Luthfi, Fakhruddin (2019) dalam penelitiannya yang berjudul "Pengaruh Mazhab dalam Regulasi Wakaf di Indonesia," mengatakan pemerintah Indonesia telah merumuskan berbagai regulasi untuk mengatur dan mengelola institusi wakaf, baik berupa Undang-undang, Peraturan Pemerintah, Kompilasi, Peraturan Menteri Agama, Peraturan Badan Wakaf Indonesia, dan lain sebagainya. Fakhruddin menambahkan pelbagai ketentuan hukum dalam pelbagai regulasi tersebut tidak terlepas dari pengaruh dominasi Mazhab Syafi'i yang menjadi mazhab mayoritas masyarakat muslim Indonesia, di samping juga pengaruh mazhab Hanafi, Maliki, dan Hanbali. ${ }^{14}$ Dengan demikian dapat dikatakan bahwa penelitian Fakhruddin ini sebagai penelitian lanjutan dari penelitian Moh Luthfi yang mengkaji pengaruh mazhab fikih dalam pembaharuan hukum wakaf dalam UU.No.41 tahun 2004 tentang wakaf.

Berbeda dengan pelbagai peneltian di atas, dalam penelitian ini akan mengkaji aspek konstruksi metodologis yang digunakan pada pembaharuan hukum wakaf dalam UU No.41 tahun 2004 tentang wakaf melalui perspektif metode ijtihad kontemporer yang dicetuskan Yususf Qaradawi, yakni ijtihad intiqa'i, ijtihad insha'i, dan integratif ijtihad intiqa'i-insha'i. Namun dalam penelitian ini akan difokuskan pada pembaharuan eksistensi wakaf (pasal 1), objek harta benda (pasal 16), dan status perubahan status harta benda wakaf (pasal 40).

13 Moh. Luthfi, "Pergeseran Paradigma Perwakafan Di Indonesia (Studi Analisis Hukum Wakaf Sebelum Dan Sesudah Berlaku Undang-Undang No. 41 Tahun 2004Tentang Wakaf)," (Disertasi Pascasarjana Universitas Islam Negeri Raden Intan Lampung, 2019 M)

${ }^{14}$ Fakhruddin, "Pengaruh Mazhab Dalam Regulasi Wakaf Di Indonesia," Jurisdictie: Jurnal Hukum dan Syariah Vol. 10 No.2 (2019). 


\section{METODE PENELITIAN}

Penelitian ini bersifat kualitatif dalam bentuk studi pustaka (library research). ${ }^{15}$ Sumber data utama yang digunakan adalah Undang-undang No.41 tahun 2004 tentang wakaf, dan sumber data sekunder berupa pelbagai hasil penelitian ilmiah yang menjelaskan tentang pembaharuan hukum wakaf di Indonesia. ${ }^{16}$ Jenis penelitian ini masuk ke dalam kategori penelitian hukum Islam normatif-filosofis. ${ }^{17}$ Pendekatan penelitian yang digunakan, yakni filsafat hukum Islam dengan menggunakan teori analisis berupa tipologi ijtihad kontemporer yang dicetuskan oleh Yusuf al-Qaradawi.

\section{KONSEP POLA IJTIHAD DAN DISKURSUS ONTOLOGIS WAKAF}

\section{Pola Ijtihad Hukum Islam Kontemporer Perspektif Yusuf Qaradawi}

Penting disadari kembali bahwa pemikiran hukum Islam (fikih) merupakan produk ijtihad seorang ulama ahli fikih terhadap landasan normatif Islam (baik al-Qurean maupun Hadis) di suatu tempat, waktu, dan kondisi sosial tertentu. Oleh sebab itu, tidak mengherankan jika produk pemikiran hukum Islam beragam bahkan kadang bertolak belakang meski

${ }^{15}$ Penelitian kualitatif merupakan penelitian yang bertujuan untuk menganalisa objek penelitian secara holistik, deskriptif tanpa metode analisis statistik. Lexy J. Moleong, Metodologi Penelitian Kualitatif (Bandung : Remaja Rosdakarya, 2017), 6.

${ }^{16}$ Adapun contoh penelitian pustaka (library research), antara lain penelitian terhadap kitab suci, buku, literatur ilmiah, peraturan perundang undangan, dan lain sebagainya. Baca Panduan Karya Tulis Ilmiah Pascasarjana UIN Walisongo (Semarang : Pascasarjana UIN Walisongo, 2018), 35.

${ }^{17}$ Menurut Atho Mudzhar, terdapat tiga jenis objek penelitian hukum Islam. Pertama, penelitian hukum Islam normatif berupa kajian terhadap berbagai literatur teks hukum Islam yang bersifat mengatur, seperti ayat-ayat ahkam, hadis-hadis ahkam, kitab-kitab fikih, Undang-Undang, keputusan hukum pengadilan, fatwa mufti, maupun pemikiran hukum Islam dari tokoh, baik individu maupun kolektif. Kedua, penelitian hukum filosofis berupa kajian terhadap kontruksi metodologi pemikiran hukum Islam, seperti halnya kontruksi ushul fikih, baik aspek filsafat hukum maupun sebagai teori hukum. Ketiga, penelitian hukum empiris berupa kajian tentang perilaku dan interaksi masyarakat terhadap eksistensi hukum Islam, baik sebagai sebab, respon maupun eksistensi hukum Islam atau dampak hukum Islamberupa Atho Mudzhar, "Tantangan Studi Hukum Islam di Indonesia Dewasa Ini," IndoIslamika, Vol.2, No.1 (2012) :95-96. 
berpijak pada landasan teks normatif nas yang sama. ${ }^{18}$ Dengan kata lain terjadinya ketidaksepakatan (konsesus) pendapat hukum di kalangan para ahli fikih tentang suatu hukum atas persoalan tertentu. ${ }^{19}$

Di samping itu faktor eksternal lain yang seringkali memicu perbedaan produk pemikiran hukum Islam, yakni karena perbedaan metodologi (manhaj) yang digunakan dalam melakukan sebuah aktifitas pengggalian, perumusan maupun penetapan hukum Islam terkait persoalan tertentu. Dalam sub bab ini, akan diuraikan tentang pola ijtihad kontemporer yang dicetuskan oleh Yusuf al-Qaradawi. Namun demikian penting terlebih dahulu kita pahami apa yang dimaksud dari term ijtihad itu sendiri. Menurut Abdul Wahab Khallaf, Ijtihad merupakan bentuk pencurahan kapasitas intlektual mujathid (orang yang berijtihad) dalam upaya penggalian hukum Islam dari pelbagai dalil yang terperinci. Khallaf menambahkan bahwa terdapat dua objek ijtihad, yakni persoalan yang tidak ada penjelasan hukumnya dalam nas (al-Qur'anHadis), dan persoalan yang ada penjelasan nas hukumnya, namun dalilnya zanni (interpretable). ${ }^{20}$ Berdasarkan penjelasan tersebut, tidaklah berlebihan jika peran ijtihad dalam konteks merespon perkembangan problem hukum Islam kontemporer senantiasa dibutuhkan. ${ }^{21}$

Dalam pandangan Yusuf al-Qaradawi setidaknya terdapat tiga pola ijtihad hukum Islam yang banyak digunakan dalam menjawab pelbagai persoalan hukum Islam kontemporer. Pertama, pola intiqa'i. Pola ini digunakan untuk mengkomparasikan pelbagai pendapat fikih klasik dari

18 Athoillah Islamy, Landasan Filosofis dan Corak Pendekatan Abdurrahman Wahid Tentang Implementasi Hukum Islam di Indonesia," Jurnal Al-Adalah : Jurnal Hukum dan Politik Islam, Vol.6, No.1 (2021):60.

19 Athoillah Islamy, "Gender Mainstreaming dalam al-Qur'an dan Hadis Serta Relevansinya Terhadap Epsitemologi Hukum Islam," Jurnal Hukum Islam, Vol.15, No.1 (2017): 194.

${ }^{20}$ Abd Wahha $>$ b Khalla>f, Ilm Usu $>$ l al-Figh (Kairo: Maktabat al-Da'wat al-Islami>at, 1947), 216-217.

${ }^{21}$ Athoillah Islamy, "Pemikiran Hukum Islam Nurcholish Madjid," (Disertasi Pascasarjana Universitas Islam Negeri Walisongo Semarang, 2021), 1. 
berbagai mazhab yang ada dengan mengkaji kembali landasan epistemologisnya. Hal ini dilakukan untuk diseleksi agar menenemukan pendapat hukum yang relevan dengan konteks kasus modern yang ada. Dalam aplikasinya, pola ini memiliki pelbagai instrument sebagai acuan dalam menyeleksi pelbagai pendapat fikih klasik, antara lain, perubahan sosial dan politik serta perkembangan dunia global, pengetahuan ilmu-ilmu modern serta perkembangan dan kebutuhan zaman. Kedua, pola Insha'i. Pola ini berupa upaya untuk menemukan konklusi hukum terhadap suatu persoalan hukum yang belum pernah diputuskan hukumnya oleh para ulama klasik dengan pendekatan teori kontemporer. Ketiga, integrasi Intiqa'i dan Insha'i. Pola ini merupakan sintesa dari dua pola sebelumnya. Pada tataran implementasinya, pola ini bermaksud untuk menyeleksi berbagai pendapat hukum para ulama klasik untuk diambil yang relevan dengan konteks saat ini. Selanjutnya ditambahkan pelbagai unsur ijtihad baru, sehingga dapat menghasilkan pendapat hukum yang berbeda dari pelbagai pendapat hukum sebelumnya. ${ }^{22}$

Tiga pola ijtihad hukum Islam kontemporer di atas akan digunakan sebagai teori analisis dalam penelitian ini guna menemukan konstruksi metodologis yang digunakan dalam konstruksi pembaharuan hukum wakaf di Indonesia.

\section{Diskursus Ontologis Wakaf dan Aspek Hukumnya}

Penting diketahui bahwa keberadaan wakaf dapat menjadi salah satu sumber keuangan publik dalam Islam. ${ }^{23}$ Eksistensi wakaf dipandang memiliki dua dimensi makna ajaran Islam sekaligus yaitu dimensi spiritual sebagai bentuk taqarrub kepada Allah dan dimensi sosial sebagai bentuk kontribusi

\footnotetext{
${ }^{22}$ Yusuf al-Qaradawii, al-Ijtihad al-Mu'asirah Baina al-Indibat wa al-Infirat (Kairo : Dar alTauzi' wa al-Nashr al-Islamiyah, 1994M), 20-36..

${ }^{23}$ Samud, "Pembaharuan Hukum Islam Dalam Pemberdayaan Wakaf Produktif Terhadap Kesejahteraan," Mahkamah, Vol. 4, No. 1, (2019): 100.
} 
terhadap peningkatan kemaslahatan kehidupan umat. Berdasarkan orientasi mulia tersebutlah, wakaf tidak boleh dikelola melalui aktifitas atau usaha yang bertentangan dengan syariat Islam sendiri. ${ }^{24}$

Term wakaf tidak ditemukan dalam landasan teologis Islam, baik alQuran maupun Hadis. Namun makna dan kandungan wakaf termuat dalam dua sumber utama hukum Islam tersebut. Dalam al-Quran sendiri misalnya, seringkali dinyatakan konsep wakaf dengan ungkapan yang menyatakan tentang sikap kedermawanan harta (infaq) demi kepentingan umum. Sedangkan dalam hadits sering ditemui ungkapan wakaf dengan ungkapan habs (tahan). ${ }^{25}$ Lantas bagaimana definsi wakaf menurut para ulama?

Sebelum memahami penjelasan dari para ulama, maka terlebih dahulu kita pahami term wakaf, baik secara etimologis maupun terminologis. Secara bahasa wakaf berasal dari bahasa Arab وقف يقف وققا berarti berhenti, mencegah, menahan. ${ }^{26}$ Sedangkan menurut istilah yang dikemukakan Jurjani bahwa wakaf menurut syara' adalah menahan zat suatu benda dalam pemilikan si wakif (orang yang berwakaf) dan mempergunakan manfaatnya. ${ }^{27}$ Sementara itu, Wahbah al-Zuhaili merangkum pendapat dari para ulama mazhab terkait definisi wakaf, sebagai berikut.

a. Imam Hanafi mendefenisikan wakaf dengan menahan suatu benda yang menurut hukumnya tetap menjadi milik wakif dan mempergunakan manfaatnya untuk kebaikan. Dalam konteks ini, wakaf tidaklah melepaskan kepemilikan wakif terhadap harta yang diwakafkannya.

${ }^{24}$ Moh. Luthfi, "Pergeseran Paradigma Perwakafan Di Indonesia (Studi Analisis Hukum Wakaf Sebelum Dan Sesudah Berlaku Undang-Undang No. 41 Tahun 2004Tentang Wakaf)," (Disertasi Pascasarjana Universitas Islam Negeri Raden Intan Lampung, 2019 M),1

25 Buku Pedoman Pengelolaan dan Perkembangan Wakaf (Kementrian Agama

Republik Indonesia Direktorat Jendral Bimbingan Masyarakat Islam Direktorat Pemberdayaan Wakaf Tahun 2013), 25.

26Ibn Manzur, Lisan al-'Arab (Beirut : Dar al-Sadr, 1990), 359. Lihat juga Ahmad Warson Munawwir,Kamus al-Munawwir Arab-Indonesia, (Yogyakarta : Pesantren Krapyak, 1984), h. 1683

27Jurjani, Ta'rifat, (Beirut : Dar al-Kutub al-'ilmiyah, 1983), 253 
Oleh sebab itu, wakif berhak menarik kembali harta wakafnya dan juga diperbolehkan untuk menjualnya.

b. Jumhur ulama (inilah yang menjadi dasar fatwa bagi sebagian golongan Hanafiyah, Syafi'iyah dan Hanabilah). Menurut mereka mendefinisikan wakaf sebagai bentuk menahan suatu benda yang dapat diambil manfaatnya. Namun berimplikasi pada hak wakif terhadap benda wakaf tersebut menjadi terputus. Hasil atau manfaat benda wakaf digunakan untuk kebaikan dalam rangka untuk mendekatkan diri kepada Allah. Dengan demikian kepemilikan benda wakaf beralih dari milik wakif menjadi milik Allah.

c. Mazhab Maliki berpendapat bahwa wakaf merupakan perbuatan wakif menjadikan manfaat hartanya untuk digunakan oleh penerima wakaf. Dalam konteks ini benda wakaf dapat berupa upah, atau menjadikan hasilnya untuk dapat digunakan, seperti mewakafkan uang. Namun dalam mazhab Maliki ini, keberadaan akad wakaf dapat dilakukan dengan masa tertentu sesuai dengan keinginan pemilik. Dengan kata lain harta wakaf masih tetap dimiliki oleh wakif. ${ }^{28}$

Berdasarkan uraian pendapat para ulama mazhab di atas dapat disimpulkan bahwa kendatipun mereka mendefinisikan wakaf sebgai institusi akad sosial (tabaaru') dalam rangka memberikan nilai kemanfaatan suatu benda untuk kemaslahatan publik. Namun terjadi distingsi pendapat ketentuan hukum di antara mereka tentang hak kepemilikian benda yang diwakafkan dan durasi waktu atas pemanfaaatan benda wakaf.

Sementara itu dalam konteks Indonesia, penjelasan atas definsisi wakaf sebagaimana yang termaktub dalam Kompilasi Hukum Islam (KHI) Pasal 215, bahwa wakaf merupakan perbuatan hukum seseorang atau kelompok orang (badan hukum) yang memisahkan sebagian benda miliknya dan

${ }^{28}$ Wahbah al-Zuhaili, al-Washaya wa al-Waqfu fi al-Figh al-Islami, (Damaskus : Dar alFikr, tt), 153-156 
melembagakannya selama-lamanya untuk kepentingan ibadah atau kebutuhan umum lainnya sesuai dengan ajaran Islam. ${ }^{29}$

Sedangkan terkait hukum wakaf, menurut Imam Malik, Imam Syafi'iy dan Imam Ahmad, hukum wakaf, yakni sunnah (mandub). Sementara ulama Hanafiyah menuturkan bahwa hukum wakaf adalah mubah (boleh). Hal ini disebabkan wakaf non muslimpun hukumnya sah. ${ }^{30}$ Dari sini dapat dikatakan bahwa di kalangan ulama Mazhab (Imam Abu Hanifah, Imam Malik, Imam Syafi'i dan Imam Ahmad bin Hanbal) tidak terdapat perbedaan pendapat hukum yang signifikan tentang hukum wakaf.

\section{E. DINAMIKA HISTORIS PEMBAHARUAN HUKUM WAKAF DI INDONESIA}

Keberadaan wakaf di Indonesia dapat diasumsikan sudah ada jauh sebelum kemerdekaan. ${ }^{31} \mathrm{Hal}$ ini ditandai dengan ditemukannya praktek yang menyerupai wakaf seperti "Tanah Perdikan" di Mataram, "Tanah Pareman" di Lombok, "Huma Serang" di Banten, "Tanah pusako" di Minang Kabau dan "Tanah Weukeuh" (tanah pemberian sultan untuk kepentingan umum, meunasah, dan masjid) di Aceh. ${ }^{32}$ Pada konteks tradisi pemeliharaan meunasah di Aceh sejak dulu diurus oleh Teuku Imum Meunasah (ulama kecil di kampung), yang mana upah Teuku Imum dan biaya pemeliharaan meunasah diambil dari hasil perkebunan yang diwakafkan. ${ }^{33}$

${ }^{29}$ Baca Kompilasi Hukum Islam (KHI) Pasal 215.

${ }^{30}$ Buku Pedoman Pengelolaan dan Perkembangan Wakaf (Kementrian Agama Republik Indonesia Direktorat Jendral Bimbingan Masyarakat Islam Direktorat Pemberdayaan Wakaf Tahun 2013), 28-29.

${ }^{31}$ Dalam konteks Indonesia sendiri, keberadaan hukum Islam telah menjadi bagian dari sistem hukum yang berlaku di tengah kehidupam masyarakat sejak syiar ajaran Islam tiba di bumi Nusantara. Athoillah Islamy, "Dinamika Historis Otoritas Hak Kepenghuluan Nikah di Indonesia," Islamitsch Familierecht, Vol.1, No.1 (2020): 8.

${ }^{32}$ Tuti A. Najib dan Ridwan al-Makassary, Wakaf, Tuhan dan Agenda Kemanusiaan : Studi tentang Wakaf dalam Perspektif Keadilan Sosial di Indonesia, (Jakarta : Center for the Study of Religionand Culture, 2006), 72-73

33Taufik Abdullah, Agama dan Perubahan Sosial, (Jakarta : Rajawali dan Yayasan Ilmuilmu Sosial,1983), 15-17 
Sementara itu, pada zaman Hindia Belanda, tanah wakaf mulai diatur dengan Sirculair Van de Government Secretaris ada tanggal 31 Januari 1905 No. 435,34 surat edaran atau BS tanggal 4 Juni 1931 N0. 1961 dan No. 12573 tentang perlunya wakif meminta izin secara resmi kepada Bupati, Kemudian dikuatkan lagi dengan BS tanggal 24 Desember 1934 No. 13390. Namun demikian penting disadari bahwa berbagai surat edaran tersebut berupa aturan administrasi wakaf agar tidak bertentangan dengan kebijakan pemerintahan Hindia Belanda.

Kemudian pada masa kemerdekaan, barulah wakaf mendapat payung hukum dari Undang-undang No. 5 Tahun 1960 Tentang Agraria Pasal 49 ayat (3) yang berbunyi : perwakafan tanah milik dilindungi dan diatur menurut peraturan pemerintah. Pasal ini ditegaskan lagi oleh PP No. 10 Tahun 1961 tentang Pendaftaran Tanah. Tindak lanjut dari UU tersebut, lahirlahPP No. 28 Tahun 1977 Tentang perwakafan Tanah Milik yang bertujuan untuk menjadikan tanah wakaf sebagai suatu lembaga keagamaan khususnya bagi umat Islam. ${ }^{35}$

Selain regulasi di atas, pada tanggal 10 Juni 1991 dikeluarkanlah juga Instruksi Presiden RI No. 1 Tahun 1991 Tentang Kompilasi Hukum Islam $(\mathrm{KHI})$, sebagai pedoman bagi para hakim Peradilan Agama dan hukum perkawinan, kewarisan serta perwakafan. ${ }^{36}$ Demikianlah awal perjalanan

${ }^{34}$ Yang isinya berupa perintah kepada para Bupati agar membuat daftar rumah ibadah yang dibangun di atas tanah wakaf, agar tidak bertentangan dengan kepentingan umum seperti pembuatan jalan dan pasar. Rifqiawati Zahara, Perkembangan Hukum Wakaf di Indonesia, Legitima : Vol. 2 No. 1 Juni 2019

${ }^{35}$ Wajid, Farid, Wakaf dan Kesejahteraan Umat: Filantropi Islam yang Hampir Terlupakan, (Yogyakarta : Pustaka Belajar, 2007), 41-47.

${ }^{36}$ Kompilasi Hukum Islam (KHI) lahir berdasarkan Instruksi Presiden RI Nomor 1 Tahun 1991. Keberadaan KHI tersebut merupakan instrumen hukum yang mengatur tentang perkawinan, perceraian dan wakaf di Indonesia. Setidaknya terdapat tiga fungsi dari eksistensi KHI. Pertama, sebagai kodifikasi dan unifikasi hukum Islam secara nasional.. Kedua, sebagai pedoman hakim Peradilan Agama dalam memutuskan hukum persoalan dalam wewenangnya. Ketiga, sebagai pedoman umat Islam terkait ketentuan hukum keluarga Islam. Athoillah Islamy, "Eksistensi Hukum Keluarga Islam di Indonesia dalam Kontestasi 
pembaharuan hukum wakaf di Indonesia hingga sampai pada kelahiran Undang-undang No. 41 Tahun 2004 Tentang Wakaf.

Secara umum, pembaharuan hukum wakaf dalam UU No. 41 Tahun 2004 tersebut meliputi tiga aspek sebagai berikut :

a. Aspek legalitas (sertifikasi)

Dalam literatur fikih, wakaf dinyatakan sah dilakukan secara lisan atas dasar kepercayaan. Wakaf dapat diserahkan pada salah satu tokoh agama yang kemudian diangkat menjadi nazhir. Namun praktek wakaf demikian dalam konteks kehidupan Indonesia modern yang serba administratif memicu pelbagai permasalahan yang berujung sengketa. Oleh karena itu, UU No 41 tahun 2004 mengatur tentang upaya sertifikasi terhadap tanah wakaf yang belum memiliki sertifikat. Dalam UU tersebut juga menetapkan aturan bahwa wakaf sah bila dilakukan di hadapan Pembuat Akta Ikrar Wakaf (PPAIW) dengan melampirkan bukti legalitas dari harta yang diwakafkan.

b. Aspek Pengelolaan, pengembangan dan pembinaan

UU No.41 tahun 2004 mengatur secara detail tentang manajemen dalam pemberdayaan dan pengembangan asset wakaf. Aturan itu menyangkut benda wakaf, nazhir, ikrar wakaf hingga dibentuknya Badan Wakaf Indonesia (BWI) sebagai penyelenggara administrasi pengelolaan secara nasional untuk membina para nazhir agar lebih professional.

c. Ketentuan pidana dan sanksi

Kepada pihak yang sengaja menyalahgunakan benda wakaf akan diancam dengan pidana penjara 5 tahun atau denda paling banyak Rp. 500.000.000. Sedangkan pihak yang sengaja merubah peruntukan benda wakaf akan dipidana penjara paling lama 4 tahun

Politik Hukum dan Liberalisme Pemikiran Islam," Al-Istinbath : Jurnal Hukum Islam, Vol.4, No.2 (2019) : 164. 
dan/atau denda sebanyak Rp.400.000.000. Sanksi administrasi ini dikenakan pada lembaga keuangan syari'ah dan PPAIW yang melakukan pelanggaran terhadap pendaftaran tanah wakaf. Hal ini dilakukan untuk menjaga benda wakaf dari penyalahgunaan oleh pihak-pihak tertentu.

Penting diketahui bahwa beberapa poin pembaharuan di atas tidak lain, dimaksudkan untuk memaksimalkan potensi wakaf sebagai salah satu asset ekonomi umat. Selain dari tuntutan zaman yang mengharuskan adanya legalitas kepemilikan tanah wakaf, munculnya regulasi tersebut juga dilatarbelakangi oleh kebutuhan masyarakat akan aturan-aturan yang mampu meminimalisir konflik wakaf yang muncul di masyarakat ${ }^{37}$ Dengan kata lain, pembaharuan ketentuan hukum wakaf tersebut dilandaskan atas terwujudnya tujuan wakaf yang sebenarnya bisa terealisasi dengan baik sesuai anjuran syari'at.

\section{F. KONSTRUKSI IJTIHAD TERKAIT EKSISTENSI WAKAF DAN BENDA WAKAF DALAM UNDANG-UNDANG NOMOR 41 TAHUN 2004 TENTANG WAKAF}

Penting diketahui bahwa dalam Undang-Undang Nomor 41 Tahun 2004 tentang Wakaf terdiri dari 11 bab dengan jumlah 71 pasal. Namun dalam penelitian ini tidak semua pasal manjdi objek penelitian. Hanya beberpa pasal antara lain, pasal 1 tentang definisi wakaf, pasal 16 tentang harta benda

\footnotetext{
${ }^{37}$ Adanya sistem manajemen dalam praktik perwakafan merupakan salah satu aspek pembaruan hukum wakaf di Indonesia. Di mana dalam paradigma lama, praktik wakaf selama ini lebih mementingkan pelestarian dan keabadian benda wakaf. Hal demikian berbeda dengan paradigma baru yang lebih menekankan pada aspek pemanfaatan tanpa kehilangan eksistensi benda wakaf itu sendiri. Untuk mwewujudkan tujuan tersebut maka dibutuhkan sistem keadministrasian dan dibentuknya suatu organisasi yang mengatur terlaksananya perwakafan tersebut. Keadministrasian yang dimaksud adalah mencakup semua pengaturan administratif terhadap unsur yang ada dalam perwakafan. Miftahul Huda, "Arah Pembaharuan Wakaf Indonesia," Ulumuna :Jurnal Studi Keislaman, Vol.16 No. 1 (2012): 139.
} 
wakaf, dan pasal 40 tentang perubahan status benda wakaf.Adapun kerangka metodologi ijtihad terkait berbagai pasal tersebut dapat dilhat dalam analisis sebagai berikut.

Pada pasal 1 UU No.41 tahun 2004 dinyatakan bahwa eksistensi wakaf merupakan bentuk perbuatan hukum wakif (orang yang berwakaf) untuk memisahkan atau menyerahkan sebagian harta benda wakaf miliknya agar dapat dimanfaatkan selamanya atau dalam jangka waktu tertentu untuk keperluan ibadah dan atau kesejahteraan umum yang tidak bertentangan dengan syariat Islam. ${ }^{38}$ Dengan kata lain wakaf dengan jangka waktu tertentu diperbolehkan. Ketentuan tersebut tidak paralel dengan pendapat mayoritas mazhab Shafiiyah, Hanabilah dan Hambaliyah yang mengharuskan pemberian objek wakaf bersifat permanen tidak boleh temporal (dibatasi waktu tertentu). Namun konstruksi hukum pada pasal 1 tersebut sejalan dengan mazhab Maliki yang tidak mensyaratkan praktik wakaf bersifat permanen (selamanya), melainkan dapat bersifat temporal..$^{39}$

Melihat ketentuan hukum dalam Pasal 1 di atas yang memperbolehkan praktik wakaf berjangka waktu, maka dapat dikatakan bahwa pembaharuan hukum wakaf tersebut melalui pola ijtihad intiqa'i. Penting diketahui kembali bahwa tujuan dari aplikasi pola ijtihad intiqai, yakni memilih pendapat fikih klasik yang relevan dengan konteks konteks dan kebutuhan masyarakat modern yang ada. Pada konteks diperbolehkannya wakaf berjangka dalam ketentuan hukum pasal 1 dapat dikatakan sebagai bentuk ijtihad pembaharuan hukum wakaf di Indonesia agar dapat relevan dan mengakomodir adanya perkembangan objek wakaf di zaman modern.

Pola ijtihad intiqa'i juga dapat dilihat pada konstruksi hukum pada pasal 15 terkait harat benda wakaf. Dalam pasal tersebut dijelaskan bahwa harta benda wakaf terdiri dari dua jenis. Pertama, harta benda tidak bergerak

\footnotetext{
38 Pasal 1, UU No.41 Tahun 2004 tentang Wakaf

${ }^{39}$ Wahbah al-Zuhaili, al-Washaya wa al-Waqfu fi al-Figh al-Islami, 153-156
} 
meliputi: hak atas tanah, hak atas bangunan atau bagian bangunan yang berdiri di atas suatu tanah hak atas tanaman dan benda lainnya yang berkaitan dengan tanah, hak milik atas rumah susun, dan hak milik atas benda tidak bergerak lainnya yang sesuai dengan ketentuan syariah dan peraturan perundang-undangan yang berlaku. Kedua, harta benda bergerak. Yang dimaksud dengan harta benda bergerak di sini meliputi: uang, logam mulia, surat berharga, kendaraan, hak atas kekayaan intelektual, hak sewa, dan benda bergerak lainnya sesuai dengan ketentuan syariah dan peraturan perundang-undangan yang berlaku. ${ }^{40}$

Jika dipahami secara mendalam bahwa konstruksi ketentuan hukum pada Pasal 16 di atas dapat dikatakan paralel dengan pendapat hukum dari tiga mazhab, yakni Maliki, Syafi'i, dan Hanbali. Di mana ketiga mazhab tersebut membolehkan harta benda bergerak sebagai objek wakaf. Hal demikian bersebarangan dengan mazhab Hanafi yang tidak membolehkan harta benda wakaf yang bergerak dengan alasan syarat wakaf antara lain selamanya ( $\left.t a^{\prime} b i d\right)$. Syarat tersebut tidak ditemukan dalam harta benda bergerak $^{41}$ Dengan kata lain, ketentuan hukum dalam pasal 16 menunjukan bahwa objek wakaf sudah tidak lagi mesti berupa harta benda bergerak, seperti halnya berupa jasa atau profesi yang diwakafkan dalam ketentuan waktu tertentu. ${ }^{42}$ Ketentuan hukum dalam pasal tersebut mencerminkan adanya konstruksi pola ijtihad intiqa'i yang memasukan pertimbangan kontemporer dalam merespon perkembangan harta benda sebagai objek zakat yang dinamis.43 Sebagaimana penting disadari dalam konteks kehidupan

40 Pasal 16, UU No.41 Tahun 2004 tentang Wakaf

${ }^{41}$ Fakhruddin, "Pengaruh Mazhab Dalam Regulasi Wakaf di Indonesia," Jurisdictie: Jurnal Hukum dan Syariah Vol. 10 No.2 (2019): 270.

${ }^{42}$ Athoillah Islamy, Doni Setiadi, "Tracking The Validity Of Profession Waqf In A Positive Legal Perspective In Indonesia," AL-'Adl, Vol. 13 No. 1 (2020) : 1-2.

${ }^{43}$ Dari segi sejarah, wakaf telah memainkan peran yang sangat penting dalam meningkatkan kehidupan ekonomi umat Islam di seluruh belahan dunia. Fungsi pokok wakaf yang erat kaitannya dengan amalan ibadah harus diikuti dengan berbagai upaya kreatif dalam menjalankan fungsi ekonomi yang dikandungnya. Paradigma modern pengelolaan 
masayarakat muslim modern, terjadi pengembangan objek wakaf yang signifikan seperti halnya praktik wakaf tunai (uang). ${ }^{44}$ Fenomena wakaf uang tersebut dalam perspektif ushul fiqh sendiri dapat dikaji melalui teori maqashid syari'ah (pelbagai tujuan dari pensyariatan hukum Islam). Di mana tujuan dari semua philanthropi Islam, yakni untuk mewujudkan kesejahteraan bersama. Oleh sebab itu, implikasi sosial dari wakaf uang dapat menjadi medium dalam realisasi kesejahteraan sosial bagi masyarakat luas 45 Hal tersebut juga menunjukan pentingnya menjadikan peran institusi wakaf tidak sebatas untuk menyediakan sarana ibadah dan sosial, melainkan juga memiliki kekuatan ekonomi untuk memajukan kesehjatraan umum. ${ }^{46}$

Selain pasal 1 dan pasal 16, pola ijtihad intiqa'i juga dapat kita lihat pada konstruksi hukum dalam pasal 40 yang menjelaskan tentang perubahan status harta benda wakaf. Pada pasal 40 tersebut dinyatakan bahwa harta benda wakaf yang sudah diwakafkan tidak dibolehkan untuk dijadikan jaminan, disita, dihibahkan, dijual, diwariskan, ditukar maupun dialihkan dalam bentuk pengalihan hak lainnya. Konstruksi hukum pada pasal 40 tersebut paralel dengan pendapat hukum mazhab Maliki dan Syafi'i yang tidak memperbolehkan untuk menjual harta benda wakaf. Berbeda dengan pendapat hukum mazhab Hanafi dan Hanbali yang tidak melarang mengatakan tindakan untuk menjual harta benda wakaf. ${ }^{47}$ Dengan demikian

aset wakaf secara produktif menuntut mekanisme pengelolaan yang lebih maju dengan segala bentuk dan ruang untuk berinovasi yang tujuan akhirnya adalah menjalankan dan menjalankan fungsi ekonomi. Beberapa negara Muslim telah berhasil melakukan langkah tersebut. Sofiandi, "Towards Reformulation of Waqf:An Indonesians Discourse," Asia Pacific Journal On Religion and Society, Vol. 03 Issue.2 (2019): 40.

${ }^{44}$ Aam Slamet Rusydiana, Yayat Hidayat, Tika Widiastuti, Solihah Sari Rahayu, "Cash Waqf for Developing Islamic Economy: Case Study in Indonesia," Al-Uqud: Journal of Islamic Economics, Vol. 5, Issue.1(2021): 43-44.

${ }^{45}$ Muzakkir S, "Wakaf Uang Dan Implikasi Sosial Perspektif Ushul Fiqh," Tafaqquh: Jurnal Hukum Ekonomi Syariah Dan Ahawl As Syahsiyah, Vol.4, No.2 (2019):20.

${ }^{46}$ Abdul Haris Naim, "Pengembangan Objek Wakaf Dalam Fiqih Islam Dan Hukum Positif Di Indonesia," ZISWAF, Vol. 4, No. 2 (2017): 256.

${ }^{47}$ Fakhruddin, "Pengaruh Mazhab Dalam Regulasi Wakaf di Indonesia," Jurisdictie: Jurnal Hukum dan Syariah, Vol. 10 No.2 (2019): 271. 
dapat disimpulkan bahwa konstruksi hukum pada pasal 40 lebih memilih pendapat hukum dari mazhab Maliki dan Syafi'i yang tidak membolehkan untuk menjual atau mengganti harta benda yang sudah diwakafkan. Namun demikian, penulis kurang sependapat dengan konstruksi hukum pasal 40 tersebut, mengingat dalam ranah praksisnya, bisa jadi benda yang sudah diwakafkan mengalami kerusakan yang berdampak pada berkurangnya bahkan hilangnya kemanfaatan dari benda wakaf tersebut. ${ }^{48}$ Oleh sebab itu, larangan penggantian benda wakaf (istibdal wakaf) sebagaiman yang termaktub dalam pasal 40 masih dapat dikoreksi kembali.

\section{F. KESIMPULAN}

Berdasarkan uraian pembahasan penelitian ini dapat disimpulkan bahwa kontruksi metodologis pembaharuan hukum wakaf yang termaktub dalam UU No.41 tahun 2004 tentang wakaf dapat dikatakan cenderung menggunakan pendektan ijtihad intiqa'i. Kesimpulan demikian dapat dilihat sebagaimana dalam Pasal 1 terkait eksistensi wakaf, Pasal 16 terkait objek wakaf, dan Pasal 40 terkait perubahan status harta benda wakaf. Konstruksi hukum dalam ketiga pasal tersebut cenderung menggunakan pola memilih pendapat hukum mazhab fikih klasik yang relevan dengan kondisi perkembangan dan kebutuhan masyarakat modern dalam dunia perwakafan. Hanya saja dalam konteks konstruksi hukum pasal 40 terkait perubahan status harta benda wakaf, penulis memandang adanya kecenderungan pemilihan pendapat hukum dari mazhab fikih klasik yang tidak membolehkan untuk menjual atau mengganti harta benda wakaf. Konstruksi hukum yang demikian dalam ranah praksisnya dapat menimbulkan problem. Mengingat bisa jadi benda yang sudah diwakafkan dalam kondisi tertentu mengalami kerusakan yang berdampak pada berkurangnya bahkan hilangnya

\footnotetext{
${ }^{48}$ Atep Hendang Waluya,"Istibdal Wakaf Dalam Pandangan Fukaha Klasik Dan Kontemporer," Misykat Al-Anwar Jurnal Kajian Islam Dan Masyarakat, Vol.29, No.2 (2018): 64.
} 
kemanfaatan. Oleh karena itu, larangan penggantian benda wakaf (istibdal wakaf) dalam pasal 40 dapat dikoreksi kembali ke arah konstruksi hukum yang lebih baik

\section{DAFTAR PUSTAKA}

Abdullah, Agung 2020. “Nadzir dalam Perspektif Kelembagaan Wakaf di Indonesia," Jurnal Ilmiah Ekonomi Islam, Vol.6, No.3.

Abdullah, Taufik. 1983. Agama dan Perubahan Sosial, Jakarta : Rajawali dan Yayasan Ilmu-ilmu Sosial.

al-Qaradawi, Yusuf. 1994. al-Ijtihad al-Mu'asirah Baina al-Indibat wa al-Infirat Kairo : Dar al-Tauzi' wa al-Nashr al-Islamiyah.

al-Zuhaili, Wahbah. al-Washaya wa al-Waqfu fi al-Figh al-Islami, (Damaskus : Dar al-Fikr, $\mathrm{tt}$

Asni.2014. "Pengembangan Hukum Perwakafan di Indonesia," Jurnal Al-'Adl, Vol.7, No.2.

Fakhruddin. 2019. "Pengaruh Mazhab Dalam Regulasi Wakaf Di Indonesia," Jurisdictie: Jurnal Hukum dan Syariah Vol. 10 No.2.

Farid, Wajid. 2007. Wakaf dan Kesejahteraan Umat: Filantropi Islam yang Hampir Terlupakan, Yogyakarta : Pustaka Belajar, 2007.

Fiqih Wakaf Proyek Peningkatan Zakat dan Wakaf Direktorat Jenderal Bimas Islam dan Penyelenggaraan Haji, 2003

Huda, Miftahul. 2012. “Arah Pembaharuan Wakaf Indonesia," Ulumuna :Jurnal Studi Keislaman, Vol.16 No. 1.

Islamy, Athoillah. 2017. "Gender Mainstreaming dalam al-Qur'an dan Hadis

Serta Relevansinya Terhadap Epsitemologi Hukum Islam," Jurnal Hukum Islam, Vol.15, No.1.

Islamy, Athoillah, Afina Aninnas. 2020. “Zakat And Tax Relation In Muslim

Southeast Asian Countries (Comparative Study of Zakat and Tax 
Arrangements In Indonesia, Malaysia, and Brunei Darussalam)," Li

Falah: Jurnal Studi Ekonomi dan Bisnis Islam, Vol.5, No.2

Islamy, Athoillah, Doni Setiadi. 2020. “Tracking The Validity Of Profession

Waqf In A Positive Legal Perspective In Indonesia," $A L$-'Adl, Vol. 13 No. 1.

Islamy, Athoillah. 2019. “Eksistensi Hukum Keluarga Islam di Indonesia dalam Kontestasi Politik Hukum dan Liberalisme Pemikiran Islam," AlIstinbath : Jurnal Hukum Islam, Vol.4, No.2.

Islamy, Athoillah. 2020. “Dinamika Historis Otoritas Hak Kepenghuluan Nikah di Indonesia," Islamitsch Familierecht, Vol.1, No.1.

Islamy, Athoillah. 2021. "Landasan Filosofis dan Corak Pendekatan

Abdurrahman Wahid Tentang Implementasi Hukum Islam di Indonesia," Jurnal Al-Adalah : Jurnal Hukum dan Politik Islam, Vol.6, No.1. Islamy, Athoillah. 2021. "Pemikiran Hukum Islam Nurcholish Madjid," Disertasi Pascasarjana Universitas Islam Negeri Walisongo Semarang Khalla>f, Abd Wahha>b. 1947. Ilm Usu>l al-Fiqh, Kairo: Maktabat al-Da'wat al-Islami>at, 1947.

Kompilasi Hukum Islam (KHI)

Luthfi, Moh. 2019. “Pergeseran Paradigma Perwakafan Di Indonesia (Studi Analisis Hukum Wakaf Sebelum Dan Sesudah Berlaku UndangUndang No. 41 Tahun 2004Tentang Wakaf)," Disertasi Pascasarjana Universitas Islam Negeri Raden Intan Lampung

Manzur, Ibn. 1990. Lisan al-'Arab, Beirut : Dar al-Sadr

Melis. 2019. “Relevansi Agama dan Kemiskinan; Upaya Memahami Kemiskinan Secara Multidimensional dan Solusi yang ditawarkan dalam Ekonomi Islam," SALAM; Jurnal Sosial \& Budaya Syar-i, Vol.6, No.2.

Mudzhar, Atho. 2012.“Tantangan Studi Hukum Islam di Indonesia Dewasa Ini," Indo-Islamika, Vol.2, No.1. 
Muslich,Ahmad. 2016. "Peluang dan Tantangan dalam Pengelolaan Wakaf," Muaddib, Vol.06 No.2.

Muzakkir S. 2019. “Wakaf Uang Dan Implikasi Sosial Perspektif Ushul Fiqh," Tafaqquh: Jurnal Hukum Ekonomi Syariah Dan Ahawl As Syahsiyah, Vol.4, No.2.

Naim, Abdul Haris. 2017 "Pengembangan Objek Wakaf Dalam Fiqih Islam Dan Hukum Positif Di Indonesia," ZISWAF, Vol. 4, No. 2.

Najib, Tuti A, Ridwan al-Makassary. 2006. Wakaf, Tuhan dan Agenda Kemanusiaan : Studi tentang Wakaf dalam Perspektif Keadilan Sosial di Indonesia, Jakarta : Center for the Study of Religionand Culture.

Panduan Karya Tulis Ilmiah Pascasarjana UIN Walisongo (Semarang : Pascasarjana UIN Walisongo, 2018

Pedoman Pengelolaan dan Perkembangan Wakaf, Kementrian Agama Republik Indonesia Direktorat Jendral Bimbingan Masyarakat Islam Direktorat Pemberdayaan Wakaf Tahun 2013

Ridwan, Murtadho. 2017. "Wakaf dan Pembangunan Ekonomi," ZISWAF, Vol. 4, No. 1.

Rusydiana,A am Slamet, Yayat Hidayat, Tika Widiastuti, Solihah Sari Rahayu. 2021.“Cash Waqf for Developing Islamic Economy: Case Study in Indonesia," Al-Uqud: Journal of Islamic Economics, Vol. 5, Issue.1.

Samud. 2019. "Pembaharuan Hukum Islam Dalam Pemberdayaan Wakaf Produktif Terhadap Kesejahteraan," Mahkamah, Vol. 4, No. 1.

Siregar, Ibrahim. 2012. "Pembaharuan Hukum Perwakafan di Indonesia," Jurnal Tsaqafah, Vol.8, No.2.

Sofiandi. 2019.“Towards Reformulation of Waqf:An Indonesians Discourse," Asia Pacific Journal On Religion and Society, Vol. 03 Issue.2.

Suwaidi, Ahmad. 2011. "Wakaf Dan Penerapannya Di Negara Muslim," Economic: Jurnal Ekonomi dan Hukum Islam, Vol. 1, No. 2.

Undang-undang No.41 Tahun 2004 tentang Wakaf 
Memahami Pola Ijtihad...

Waluya, Atep Hendang, 2018. “Istibdal Wakaf Dalam Pandangan Fukaha Klasik Dan Kontemporer,"Misykat Al-Anwar Jurnal Kajian Islam Dan Masyarakat, Vol.29, No.2.

Warson, Ahmad. 1984. Munawwir,Kamus al-Munawwir Arab-Indonesia, Yogyakarta : Pesantren Krapyak,

Zahara, Rifqiawati 2019. Perkembangan Hukum Wakaf di Indonesia, Legitima : Vol. 2 No. 1. 